\title{
Gender diversity in the board, women's leadership and business performance
}

\author{
Jorge Moreno Gómez \\ Departamento de Gestión Organizacional, Universidad de la Costa \\ Calle No 58, 55-66. Barranquilla, Colombia \\ Email: jmoreno@cuc.edu.co \\ Esteban Lafuente \\ Department of Management, Universitat Politècnica de Catalunya (Barcelona Tech) \\ EPSEB, Av. Gregorio Marañón, 44-50, 2da planta. 08028. Barcelona. Spain \\ Email: esteban.lafuente@upc.edu \\ Yancy Vaillant \\ Department of Strategy and Entrepreneurship. Toulouse Business School (TBS) \\ 1 Place Alphonse Jourdain, 31068 TOULOUSE Cedex 7, France \\ Email: y.vaillant@tbs-education.org \\ and \\ Departamento de Gestión Organizacional, Universidad de la Costa
}

\begin{abstract}
Purpose: This paper investigates how gender diversity in top management—i.e., boardroom and top management positions-impacts business performance among Colombian public businesses. Design/methodology/approach: Building on the Upper Echelon theory which emphasizes that gender in an important characteristic that influences top management's decision making, we employ panel data models on a sample of 54 Colombian public businesses for the period 2008-2015 to test the proposed hypotheses relating gender diversity and subsequent business performance.

Findings: The results support that gender diversity is positively associated with subsequent business performance. More concretely, we find that the relationship between gender diversity at the top of the corporate hierarchy —in our case, as CEO and in the top management team-and subsequent performance becomes more evident when performance is linked to business operations (ROA), while the positive effect of women's representation in the boardroom and subsequent performance is significant when performance is measured via shareholder-oriented metrics (ROE).

Originality/value: Few studies have addressed the role of gender diversity on performance in developing economies. This study contributes to better understand how gender diversity impacts performance in contexts where women are underrepresented in the top management, and where the appointment of women directors or managers is not driven by regulatory pressures.
\end{abstract}

Keywords: Upper echelon, gender diversity, board of directors, top management, business performance.

Please cite the paper: Moreno-Gómez, J., Lafuente, E., Vaillant, Y. (2018). Gender diversity in the board, women's leadership and business performance. Gender in Management: An International Journal, in press. DOI: 10.1108/GM-05-2017-0058. 


\section{Gender diversity in the board, women’s leadership and business performance}

"When more women lead, performance improves. Start-ups led by women are more likely to succeed; innovative firms with more women in top management are more profitable; and companies with more gender diversity have more revenue, customers, market share and profits. A comprehensive analysis of 95 studies on gender differences showed that when it comes to leadership skills, although men are more confident, women are more competent. To break down the barriers that hold women back, it's not enough to spread awareness. If we don't reinforce that people need - and want - to overcome their biases, we end up silently condoning the status quo." _-Adam Grant and Sheryl Sandberg (The New York Times, December 6 2014). ${ }^{1}$

\section{INTRODUCTION}

Gender diversity at the top of the corporate hierarchy—i.e., in the boardroom and top management positions — constitutes a 'trendy topic' that has increasingly drawn scholarly and policy-making attention (Adams and Funk, 2011; Bøhren and Staubo, 2014; Terjesen et al., 2014;

Klettner et al., 2016). A quick search through the academic literature shows that the amount of scientific articles on gender diversity has grown more than ten folds between 2006 and $2016 .{ }^{2}$

Beyond the social and ethical implications, the women's representation in top positions of the corporate hierarchy may have important repercussions for business performance, not only as a signal of a more gender-neutral recruitment and promotion process, but also because of the potential benefits of gender diversity itself in terms of broadening the range of experience and expertise as well as human capital available to a team (Adams and Ferreira, 2009).

Notwithstanding the increased relevance of gender diversity in the boardroom and top management position for managers and policy makers in developed settings (see, e.g., Rose, 2007; Adams and Funk, 2011; Lückerath-Rovers, 2013; Isidro and Sobral, 2015), the performance effects of gender diversity in developing economies remains largely unaddressed (see, e.g., Lazzaretti et

\footnotetext{
${ }^{1}$ https:/www.nytimes.com/2014/12/07/opinion/sunday/adam-grant-and-sheryl-sandberg-on-discriminationat-work.html

${ }^{2}$ Search performed on Abril 11th 2017 on Web of Science using the following keywords: gender, diversity and board*. The number of hits reported varies from 9 publications in 2006 to 98 publications in 2016.
} 
al., 2013; Liu et al., 2014; Kiliç and Kuzey, 2016). Additionally, research conducted in developed countries shows inconclusive results on the relationship between gender diversity and business performance (Post and Byron, 2015), while existing work in developing countries tend to support the notion that gender diversity is conducive to performance (Sekkat et al., 2015). The reasoning for this contrast in the impact of gender diversification between firms of developing and developed economies has been suggested as being the result of the strong cognitive and human capital variety that separates male and female members of the upper corporate echelons in developing countries, which is not present in many developed economies (Jeong and Harrison, 2016). Whereas the lack of 'contrast' across gender in developed country corporate hierarchies may dilute the impact of such diversity (Klein, 2017), the exceptionality of women participation in upper echelons of firms in developing countries may make their cognitive variety contribution far more potent to the performance improvements of their businesses.

However, most studies coming from developing countries, such as those of Latin-America, have been conducted by private consultancies and non-academic institutions. There is a lack of scientific evidence of the possible positive correlations between gender diversity of the upper echelons of corporations and business performance. Thus, the debate is still open and the governance implications of gender diversity raise the question of whether a greater participation of women in the upper echelons of Latin-American firms enhances business performance.

The analysis of the relationship between women's representation in top management and performance is the focus of this study. More concretely, this paper evaluates the impact of gender diversity — in the board and in top management positions — on business performance, measured via economic and financial accounting-based variables.

The empirical application considers a unique dataset of Colombian public businesses during 2008-2015. This setting is attractive because, similar to many developed and developing economies, women account for about $43 \%$ of the country’s labor force; however, they are under-represented at the top of the corporate hierarchy: $12 \%$ of top executives and board members are women, while 
only $4 \%$ of top companies have a woman serving as CEO (ILO, 2015). Also, different from the case of various mostly European countries (e.g., Belgium, France, Iceland, Italy, the Netherlands, Norway, and Spain) (Ahern and Dittmar, 2012; Singh et al., 2015), Colombian businesses do not have to meet 'gender quotas' imposed by law. ${ }^{3}$ Despite some reforms, it is important to highlight that the Colombian legislation does not impose any quota that can artificially increases women's participation in boards and top-management positions of private organizations. Decisions related to the appointment of women in top positions of the corporate hierarchy continue to be entirely endogenous at the firm level. Therefore, the proposed study provides an opportunity to analyze how gender diversity contributes to business performance in a context of low women representation in top-management where competitive conditions are complex and heterogeneous.

This article extends the literature on board gender diversity in two main ways. First, this study looks into the role of gender diversity on various performance metrics, answering the call made by Adams and Ferreira (2009) and Kiliç and Kuzey (2016) for more research on the effects of women representation in top management in relatively unexplored settings. Also, our study complements the emerging body of work focused on the effects of gender diversity on performance in developing economies (e.g., Lazzaretti et al., 2013; Liu et al., 2014; Kiliç and Kuzey, 2016).

Second, the proposed analysis generates valuable insights with practical application. The analysis of the effects of gender diversity on performance has increasingly drawn policy makers' attention as a result of their interest in promoting gender equality in business' top hierarchical structure. By examining the performance outcomes that flow from a greater representation of women in corporate hierarchies organizations might be in a better position to understand how to better capitalize on the women's human capital as well as to evaluate the economic benefits resulting from the involvement of women in top management.

\footnotetext{
${ }^{3}$ Note that the Colombia's government has taken a first step to foster gender equality by enacting in 2000 the Act 581, a legal framework that regulates women's representation in the public administration.
} 


\section{BACKGROUND LITERATURE AND HYPOTHESES DEVELOPMENT}

Although other theories such as critical mass theory (Kanter, 1977), social categorization theory (Tajfel, 1981), social identity theory (Ashforth and Mael, 1989), and agency theory (Hillman and Dalziel, 2003; Adams and Ferreira, 2009; Adams and Kirchmaier, 2016) have been invoked to link the representation of women within corporate hierarchies to firm performance, upper echelons theory (Hambrick, 2007; Hambrick and Mason, 1984) serves as the theoretical framework underlying this study because it provides a clear theoretical foundation for linking the specific characteristics and diversity of corporate hierarchy with firm outcomes (Post and Byron, 2015; Jeong and Harrison, 2017).

Literature rooted in strategic management and within the corporate governance framework emphasizes that business behavior and its subsequent performance are, to a large extent, a function of its top management, which makes most of the relevant strategic decisions (Carpenter et al., 2004; Adams et al., 2010). Hambrick and Mason (1984) set the theoretical foundations that establish 'the organization as a reflection of its top managers' in what is known as the Upper Echelon Theory. The essence of the Upper Echelon Theory rests on the premise that the interpretations that executives make of the situations they face, and consequently their choices and decisions, are greatly influenced by their personal experiences, values, and personalities (Hambrick, 2007). The composition of the top management team of an organization therefore directly influences the potential performance of the organization they manage. Firms of comparable characteristics facing similar market conditions may have different performance levels based on the specificities of their executive team (Waldmana et al., 2004).

As part of the specificities and personal traits that characterize top-management teams which according to the premises of the Upper Echelon theory would impact the performance of organizations being managed, gender is an important feature that should be considered (Nishii et al., 2007). Gender composition is a type of non-function specific diversity that is conducive to high performance management teams, consistent with the Upper Echelon theory (Herman and Smith, 
2015). The social perspective of the feminist group of management theories (Carter and Williams, 2003) indicates that women tend to analyze situations and choose strategies that are different from men's. The link between the gender composition of the top management team of an organization and its performance is therefore not solely linked to whether a firm is male or female driven, but rather based on the gender-diversity of its executives or board.

Existing empirical studies show that by broadening the range of experience and expertise available to top-management teams or boards, diversity can promote team effectiveness. Consistent with this argument, research has found that, compared to homogeneous management teams, diverse executive teams are more innovative (Bantel and Jackson, 1989), adopt richer strategies (Bantel, 1993), respond better to competitive threats (Hambrick et al., 1996), and are quicker to implement change (Williams et al., 1995). As opposed to a team diversity composed of 'specialists', a heterogeneous team composed of individuals with a greater breadth of experiences is found to be better able to realizing the performance benefits linked to diversity (Bunderson and Sutcliffe, 2002).

Accordingly, women in corporate upper echelons — i.e., the boardroom or the top management - increase the team's diversity, in terms of both social structure and human capital (Adams and Ferreira, 2009). The introduction of qualified women to an all-male board increases the board’s cognitive variety (Oppong, 2014). The greater the upper echelon’s cognitive variety, the more options it is likely to consider and the more deeply it is likely to debate those options (Klein, 2017). The likely results of this process are more effective decisions (Robbins, 1974; Dezsö and Ross, 2012).

If gender diversity in upper corporate echelons is conducive to performance, there are likely implications for the organization (Ting et al., 2015). The value-creating potential of organizational structures with greater gender-diverse human capital may prove itself comparable or superior to that of male-controlled structures (Rose, 2007; Adams and Ferreira, 2009).

However, despite the strength of this theoretical premise, which is now well consolidated within the academic literature, no clear empirical confirmation has been found; at least not among 
the overwhelming majority of the studies done on this issue (Post and Byron, 2015; Jeong and Harrison, 2017). Some of the reasoning given to these results is that gender differences may exist among the general adult population, but male and female within corporate upper echelons may not differ that much (Klein, 2017). If this is so, gender diversity may not increase the cognitive variety of a corporate hierarchy (Jeong and Harrison, 2017).

But the majority of these studies have been conducted in economically developed countries, as seen in Post and Byron's, (2015) meta-analysis of an exhaustive list of some 140 different studies linking board gender diversity and performance. Their findings offered little support for any link between both variables, but did find that any possible relationship was stronger in countries offering greater shareholder protection. Although some studies in their analyses were set in developing countries, mostly South Asian ones, none were conducted in Latin America (Post and Byron, 2015). This would tend to contrast with studies specific to board and top management gender diversity in developing countries that have tended to show a positive link between the participation of women in the upper echelons of a firm and firm performance (see, e.g., Liu et al., 2014; Ararat et al., 2015; Kiliç and Kuzey, 2016). Specifically, studies in Latin America have found that the introduction of a critical mass of women within the upper echelons of a firm significantly and positively affected performance (Delloite, 2015; 2017). However, most of these studies have been conducted by private consultancy groups, and little is available in the way of peer-reviewed academic research on the subject.

Gender diversity in the upper echelons of Latin-American firms is found to be conducive to greater performance and this in spite of corporations in these countries lag behind their global peers in appointing women to their hierarchies (CWDI, 2015). Using the same argument used to explain why board gender diversity in developed countries has little or no effect on performance- - the lack of cognitive variety introduced as a result of strong similarities between male and female board members (Klein, 2017)—could therefore explain the positive impact over performance of gender diversity in Latin-America's businesses. The gender gap in Latin America is considerably greater 
than what can be found in most developed economies (World Economic Forum, 2015). The exceptionality and 'difference’ women bring to the hierarchy of these organizations has greater potency in Latin-America than it may have in countries with less important gender gaps.

Colombia, however, stands out as the regional leader in placing women within the upper echelons of firms (CWDI, 2015). This is in spite of the fact that Colombia has no specific legislation mandating gender diversity within corporate boards. The analysis presented in this paper is therefore meant to scientifically study how gender diversity impacts performance in Colombia. We argue that the effects of gender diversity on performance will help unveil whether Colombian firms capitalize on their gender-diverse human capital to achieve the desired goal of maximizing performance as would be expected from the dominant theoretical postulates in the related academic literature.

Research following the upper echelon theory has adopted two different units of analysis; the governance team and the individual CEO (Jeong and Harrison, 2017). This study embraces both approaches as the former allows investigation of group-level mechanisms whereas the latter is suitable for individual difference-based theorizing. We therefore focus on the gender diversity at two distinct levels of organizational governance: at the level of the board, and within the top management team led by women (in our case, as CEO).

\section{Gender diversity: Women representation in the board of directors}

Boards play a central role in the organization by monitoring managers and providing valuecreating knowledge that contributes to the corporate strategy making process (Rose, 2007; Adams et al., 2010). Within organizations, the board of directors - acting on behalf of shareholders-is an influential entity whose functioning is highly related to performance (Hermalin and Weisbach, 2003). Therefore, it is interesting to investigate how board's structure, in terms of gender diversity, affects board's decision making and, consequently, business performance. 
Previous work on the relationship between board diversity and performance has mostly focused on developed countries (see e.g., Rose, 2007; Martin et al., 2008; Lückerath-Rovers, 2013; Hillman, 2015; Isidro and Sobral, 2015; Adams and Kirchmaier, 2016). Results are inconclusive (Post and Byron, 2015). While several studies report a positive effect of women representation in boards on performance (Dwyer et al., 2003; Campbell and Mínguez-Vera, 2008; Hoogendoorn et al., 2013), research also shows that this relationship is not significant (Erhardt et al., 2003; Naranjo-Gil et al., 2008) or contingent to organizational factors (Dezsö and Ross, 2012).

The analysis of the gender diversity-performance relationship in developing economies has recently drawn scholarly attention. Examples include Mahadeo et al. (2012) for Mauritius, Liu et al. (2014) for China, and Ararat et al. (2015) and Kiliç and Kuzey (2016) for Turkey. These studies support the assumption that women are an important source of human capital for boards and that gender diversity is conducive to business performance.

To exercise their monitoring and advisory roles efficiently, boards require a variety of skills, information, experience and capabilities (Adams et al., 2010). It has been suggested that women represent a source of valuable human capital with value-creation potential and that there are two main advantages of having women on the board (Adams and Ferreira, 2009). First, women are not part of the 'old boys' network, which increase their level of independence. Second, regardless of age and education, women may bring to the board a new managerial practices that can prove themselves efficient in complementing existing ones, thus leading to improvements in the boards' functioning (Adams and Ferreira, 2009; Joecks et al., 2013). Thus, the positive relationship between gender diversity in boards and performance is indicative of the quality of the business' governance system, and of how organizations capitalize on the human capital of their board members (men and women). It has been argued that excessive diversity may cause communication and coordination costs within the board (Hillman et al., 2007); however, this concern is unlikely to be empirically relevant for most boards because the number of boards dominated by women is small. 
In general, more heterogeneous boards likely have superior knowledge stocks and different points of view and consider a wider array of solutions to specific problems, thus enhancing the quality of strategy making (Hillman et al., 2007). This is especially relevant in case where, as with the boards' decision making, the group’s tasks are high in knowledge intensity and the outcome of this process heavily relies on information processing (Van Knippenberg et al., 2004). This logic and evidence suggest the following relationship between gender diversity in boards and performance. H1: Gender diversity in the boardroom positively impacts business performance, measured as the return on assets and return on equity.

\section{Women in top executive positions}

We expect that the benefits of women representation in the boardroom are extensive to the top management team for a number of reasons. Based on survey data, Rosener (1995) finds that women’s leadership style is more interactive and participatory by encouraging input and information sharing from others, and by establishing and keeping open communication channels with their subordinates. Other authors show that in organizational settings, women are less hierarchical and more collaborative than men (Ravasi and Schultz, 2006), and that they tend to manage businesses in a more democratic way (Tang et al., 2011). Additionally, existing research suggests that women are more risk averse (Palvia et al., 2014), better at monitoring (Adams and Ferreira, 2009), and more long-term oriented when it comes to strategy making (Reguera-Alvarado, 2015). These behaviors, which we call 'feminine management style', promote the sharing of key information for the efficient functioning of the business, a critical process underlying the positive effects of gender diversity on performance (Van Knippenberg et al., 2004).

Exploring women in these specific roles is of much interest as the leadership style affects directly the strategy making process, the corporate culture and, ultimately, business performance (Krishnan and Park, 2005; Ravasi and Schultz, 2006; Tang et al., 2011). 
Although relatively few studies examine gender diversity in top management mostly because of the lack of data on women in top management teams (Adams and Funk, 2011), existing empirical research support these arguments. For example, Dwyer et al. (2003) find that the positive effect of gender diversity at the top management level on performance is moderated by the business' strategic orientation and organizational culture. In their study on CEOs and Chairwomen in the U.S. banking industry, Palvia et al. (2014) document that female CEOs and Chairpersons hold more conservative capital levels and that smaller banks with female CEOs and/or board Chairs were less likely to fail. This result corroborates that gender-based behavioral differences may affect corporate decisions. Additionally, Liu et al. (2014) report a positive relationship between the presence of a female CEO and economic performance (ROA) among public companies in China.

This theory and empirical evidence indicate that characteristics of the 'feminine management style’-which we associate with greater collaboration, nurturing, information sharing and enhanced decision making — are conducive to business performance, and suggest the following relationship between women's representation in top management teams and performance.

H2: Gender diversity in the top management team-i.e., CEO and top management positions_-positively impacts business performance, measured as the return on assets and return on equity.

\section{DATA, VARIABLE DEFINITION AND METHOD}

\section{Data}

The information used in this study comes from two sources. First, accounting and organizational data were obtained for the 2008-2015 period from the annual financial statements available at the Colombian Superintendence of the Stock Market (www.bvc.com.co). Second, information on the composition of both the board of directors and top management teams was obtained from the annual reports available at the sampled businesses’ websites. Note that information was available for 90 Colombian listed companies. However, in the interest of following 
a rigorous methodology we included in the final sample only those listed firms for which a complete dataset of dependent and independent variables can be constructed for the study period. Based on this criterion 36 businesses were excluded from the sample, and the final sample consists of 54 listed Colombian companies for the period 2008-2015 (432 firm-year observations).

\section{Variable definition}

Dependent variables. In line with prior work (see e.g., Joecks et al., 2013; Kiliç and Kuzey, 2016), we examine two dimensions of business performance based on accounting ratios. First, economic performance is measured through the rate of return on assets (ROA) which is calculated, for each firm and each period, as the operating profit divided by total assets. Second, we use financial performance — return on equity (ROE) — measured as the net profit divided by shareholders’ equity. Descriptive statistics are presented in Table 1.

--- Insert Table 1 about here ---

Gender diversity. We created three variables to measure the participation of women in the business' governance structure. Following prior studies (Adams and Ferreira, 2009; Ahern and Dittmar, 2012), we first introduce the proportion of women in the board of directors. Second, we use the proportion of women in top management positions (i.e., executive positions with the functional capacity to implement corporate strategies, such as CFO, or COO) (Reguera-Alvarado, et al., 2015). Third, we use a dummy variable taking the value of one if a woman holds the position of CEO, and zero otherwise. This variable accounts for the potentially differentiating leadership effect of women in designing the business’ strategy making and corporate management. In all model specification, these variables were lagged one period to avoid endogeneity problems related to reverse causality (Greene, 2003). 
From the descriptive in Table 1 we observe that boards of the sampled Colombian listed companies are dominated by men: only $44.50 \%$ of the sampled businesses have at least one woman in the board, and the average proportion of women in the board is $9.35 \%$. Figure 1 shows that the proportion of women in the board of directors increased between 2008 (7.60\%) and 2012 (10.39\%), and that this rate slightly fell after 2012 (proportion of women in the board in 2014: 9.01\%). Also, the average women representation in top management positions is $23.21 \%$, while $12.27 \%$ of businesses have a female CEO.

--- Insert Figure 1 about here ---

Control variables. Similar to previous work (e.g., Adams and Ferreira, 2009; LückerathRovers, 2013; Isidro and Sobral, 2015; Kiliç and Kuzey, 2016), we control for business size, leverage, the size of the top management team (TMT), board size, board independence and time in the different model specifications. Business size is measured by total assets, while leverage is measured as the ratio of debt to assets. The total number of top managers and board members was used to measure the size of the top management team and the board of directors, respectively. Board independence is measured as the ratio of non-executive directors divided by board size. Finally, we include a set of year dummy variables to rule out the effect of time and other environmental changes on performance. Similar to the case of the variables related to gender diversity, all timevarying control variables are lagged one period to avoid potential endogeneity problems.

\section{Method}

In line with the arguments that underpin this study, we employ panel data techniques to estimate the proposed model which emphasizes a relationship between gender diversity and performance. Pooling repeated observations on the same organizations violate the assumption of independence of observations, resulting in autocorrelation in the residuals. First-order 
autocorrelation occurs when the disturbances in one time period are correlated with those in the previous time period, resulting in incorrect variance estimates, rendering ordinary least squares (OLS) estimates inefficient and biased (Wooldridge, 2002). Therefore, we estimate fixed-effects panel data models with robust standard errors to take into account the unobserved and constant heterogeneity among the analyzed businesses. Also, the use of fixed-effects models controls for the potential endogeneity problems that result from the correlation between the explanatory variables and the time-invariant business-specific unobserved heterogeneity (Greene, 2003).

To evaluate the role of gender diversity empirically, the proposed full fixed-effects model has the following form:

$$
\begin{aligned}
\text { Performance }_{i t} & =\beta_{0}+\beta_{1} \text { Women in the board } \\
& +\beta_{3} \text { Women as }_{\text {CEO }}+\beta_{2} \text { Women in }_{i t-1}+\beta_{4} \text { Control variables }_{i t-1}+\eta_{i}+\varepsilon_{i t}
\end{aligned}
$$

In equation (1) $\beta_{j}$ are parameter estimates for the $j$ th independent variable, $\eta$ is the timeinvariant fixed effect that controls for unobserved heterogeneity across businesses (i), and $\varepsilon$ is the normally distributed error term that varies cross-businesses and cross-time $(t)$. Control variables include business size, business size, the size of the top management team, board size, board independence and the set of time dummy variables.

We estimated the Hausman (1978) specification test to further validate the appropriateness of the proposed fixed-effects models. Results for the full model evaluating the role of gender diversity on ROA (Hausman test: 23.55 and $p<5 \%$ ) and ROE (Hausman test: 54.19 and $p<1 \%$ ) indicate that random effects estimations are not independent of business-specific effects-i.e., regressors are inconsistent — thus confirming that fixed-effects estimations are consistent and efficient (Wooldridge, 2002).

\section{EMPIRICAL RESULTS}


The findings for the effect of gender diversity on performance are presented in this section (Table 2). For both performance variables (ROA and ROE), specifications 1 to 3 in Table 2 show the results for the models estimating performance as a linear function of the proportion of women in the board (model 1), the proportion of women in the top management team (model 2), and the role of women as CEO (model 3). Model 4 reports the results for the full model that includes all the variables linked to gender diversity.

To address the threat of collinearity, we computed the average variance inflation factor (VIF) for all variables. The average VIF value for model 4 is 1.42, and all VIF values are below the generally accepted threshold value of 10 for assessing collinearity (Greene, 2003). The results for this diagnostic test do not raise collinearity concerns.

--- Insert Table 2 about here ---

The results of the control variables included in our analysis indicate that, throughout the different model specifications applied to our sample, leverage is negatively associated with performance (ROA and ROE). Additionally, smaller businesses show higher rates of economic performance (ROA), while economic performance (ROE) is positively associated with the size of the top management team. This latter result is in line with previous work suggesting that larger top management teams create value for shareholders (Adams and Ferreira, 2009).

Concerning the fixed-effects model estimating the effect of gender diversity—i.e., women's representation in the boardroom and in the top management team—on subsequent performance, results show that gender diversity is positively associated with business performance.

Our first hypothesis states that gender diversity in the boardroom positively impacts business performance. Results partially support this hypothesis. From model 4 in table 2 we note that the positive effect of gender-diverse boards on subsequent performance is statistically significant only when performance is measured as the ratio of returns on equity (ROE) 
(Model 4: $\beta_{1}=1.5457$ and $p-$ value $<1 \%$ ). This result is consistent with prior studies dealing with the analysis of the relationship between women representation in boards and performance in developed economies (see, e.g., Campbell and Mínguez-Vera, 2008; Hoogendoorn et al., 2013) as well as in developing countries (see, e.g., Mahadeo et al., 2012; Ararat et al., 2015; Kiliç and Kuzey, 2016).

Hypothesis 2 proposes that gender diversity in the top management team-i.e., CEO and top management positions_-positively impacts business performance. This hypothesis is partially supported. More concretely, the parameter for the proportion of women in the top management is statistically significant for both ROA (Model 4: $\beta_{2}=0.1856$ and $p-$ value $<1 \%$ ) and ROE (Model 4: $\beta_{2}=3.1541$ and $p-$ value $<1 \%$ ). Similar to previous studies (Dwyer et al., 2003; Palvia et al., 2014; Terjesen et al., 2016), these results suggest that women’s leadership stylecharacterized by less hierarchical concerns, greater collaboration levels, and a more long-term oriented strategy making-is conducive to performance.

In the case of the coefficient linked to a female CEO, results indicate that positive impact of this variable is significant when economic performance (ROA) is the dependent variable (Model 4: $\beta_{3}=0.0931$ and $p-$ value $<10 \%$ ). The dissimilar findings when comparing ROA and ROE may result from the perceived informative power of each performance variable. Our results may suggest that, in our sample, investors place a greater weight on shareholder-oriented performance metrics — in our case, ROE—-because they are more informative about the effectiveness of the board in their main task: monitoring management (Engel et al., 2003).

On contrary, the results for the relationship between women's representation at the top of the corporate hierarchy—in our case, as CEO and in the top management team—and performance may indicate that the positive effects of gender diversity become more evident when performance is linked to business operations (Adams and Funk, 2011). 
Note that we conducted an additional analysis to further verify the robustness of this latter result. We computed the squared term for the size of the top management team and board size to test for a potential non-linear relationship between these variables and performance. The results, not presented but available from the authors on request, show that the linear and squared coefficients for the variables top management team size and board size are not statistically significant. These results corroborate the appropriateness of our estimation strategy and the validity of our findings.

\section{DISCUSSION, IMPLICATIONS AND CONCLUDING REMARKS}

In this study, we propose that the presence of women at the top of the corporate hierarchyi.e., in the boardroom and in the top management-positively impact business performance. We test the proposed hypotheses using a sample of 54 large Colombian public businesses for the period 2008-2015. Overall, the findings are consistent with prior studies that emphasize that gender diversity contributes to business performance (e.g., Carter et al., 2003; Adams and Ferreira, 2009; Lückerath-Rovers, 2013; Liu et al., 2014; Kiliç and Kuzey, 2016).

In the increasingly competitive business arena, gender diversity has been invoked as a 'needed solution' to increase the quality of the board's human capital, thus contributing to achieve its monitoring and strategy making goals (Carpenter et al., 2004, p. 771). Our results are in line with this view and corroborate that gender-based behavioral differences may affect corporate decisions (Carter and Williams, 2003; Hambrick, 2007).

We find that gender diversity in the board is positively associated with subsequent performance, and this result may be indicative of the quality of the business’ organizational structure, and of how businesses can generate important gains from the exploitation of a more gender-diverse board's human capital base. Additionally, beyond the merely ethical considerations, our results pointing to a positive effect of introducing women in top management position suggest that the differentiated perspectives of the 'feminine management style' create value to the business (Carter and Williams, 2003). Organizations choose board members and top managers on the basis 
of their abilities and skills seeking to achieve the desired goal of maximizing business outcomes. In this sense, our results give ammunition to the argument that the benefits of gender diversity at the top of the corporate hierarchy outweigh its costs, and that the increased presence of women in top management is especially relevant to improve knowledge intensive strategy- and decision-making tasks within the organization (Hillman et al., 2007; Van Knippenberg et al., 2004).

The results of this paper have relevant implications for scholars, policy makers and practitioners. Gender diversity has been identified as an important dimension necessary to improve the functioning of top management teams (Adams and Ferreira, 2009; Isidro and Sobral, 2015). By elaborating on the benefits associated with gender diversity, this paper contributes to better understand the impact of gender in management within corporate hierarchies in developing economies. While research conducted in developed countries shows inconclusive results on the relationship between gender diversity and performance (Post and Byron, 2015), our results are in line with prior studies that emphasize the positive effect on performance of gender diversity in developing economies (Sekkat et al., 2015; Kiliç and Kuzey, 2016). This finding fuels the academic debate on the relevance of potentially moderating factors in the relationship between gender diversity and performance. Echoing Jeong and Harrison (2016), the reported differences in the impact of gender diversity on performance across countries may well originate from the strong cognitive and human capital variety that separates male and female members of corporate hierarchies in developing countries. Contrary to the case of developed economies where the lack of 'contrast' across genders may dilute the impact of gender diversity on performance (Klein, 2017), our results suggest that the exceptionality of women participation in corporate hierarchies of businesses in developing countries may make their cognitive variety contribution far more powerful to performance improvements.

Second, in many developed and developing contexts, reforms have been introduced in an effort for increasing women’s representation in boards and top management teams (Carter et al., 2010). Although the debate on whether gender diversity should be encouraged or imposed is open 
(Ahern and Dittmar, 2012; Bøhren and Staubo, 2014), our empirical results tend to support the notion that gender-diverse structures have positive performance consequences. In this sense, policy makers should not promote gender diversity policies based on tokenism arguments (Adams and Ferreira, 2009), but rather on the economic benefits of such policies for organizations and on the social outcomes resulting from the greater inclusion of women in top management (Hillman, 2015; Kiliç and Kuzey, 2016).

Third, we suggest that managers and directors need to turn their attention to the valueadding potential of gender diversity. This is especially relevant in the context of public businesses, where the prioritization of short-term economic results—-that may fulfill investors' desires—are not always compatible with other, equally valuable, objectives. The excessive short-termism may blur the analysis of the quality of management (Fisman et al., 2014), and the greater involvement of women in top management can therefore contribute to design and pursue long-term strategic goals. In a developing context where organizations are not exposed to regulatory pressures to increase gender diversity, we believe that the results of our study make a powerful case for gender diversity and suggest that organizations that take a step forward to help women overcome barriers to their managerial advancement will often be rewarded with improvements in firm performance.

It must, however, be mentioned a series of limitations to the present study that, in turn, represent avenues for future research. First, like other studies, the data do not permit the direct analysis of the ways through which women create or contribute to the organization's strategy making. We present various interpretations of how gender diversity enhances performance; however, we do not evaluate the selection process of directors and managers, nor do we assess how subsequent performance is conditioned by directors' and managers' specific characteristics (such as age, education, tenure, experience in the sector). Further research on this issue would be valuable. Second, cultural contexts, different regulatory frameworks, and variations in the development of markets might affect the impact of gender diversity on performance. The geographic specificity of the study calls for obvious caution when interpreting and generalizing its findings. 


\section{REFERENCES}

Adams, R. and Ferreira, D. (2009), "Women in the boardroom and their impact on governance and performance”, Journal of Financial Economics, Vol. 94 No. 2, pp. 291-309.

Adams, R. and Funk, P. (2011), “Beyond the Glass Ceiling: Does Gender Matter?”, Management Science, Vol. 58 No. 2, pp. 219-235.

Adams, R., Hermalin, B.E. and Weisbach, M.S. (2010), “The Role of Boards of Directors in Corporate Governance: A Conceptual Framework and Survey”, Journal of Economic Literature, Vol. 48 No. 1, pp. 58-107.

Adams, R. and Kirchmaier, T. (2016), “Women on boards in finance and STEM industries”, American Economic Review: Papers and Proceedings, Vol. 106 No. 5, pp. 1-6.

Ahern, K. and Dittmar, A. (2012), “The changing of the boards: the impact on firm valuation of mandated female board representation”, Quarterly Journal of Economics, Vol. 127 No. 1, pp. 137-197.

Ararat, M., Aksu, M. and Tansel Cetin, A. (2015), "How board diversity affects firm performance in emerging markets: Evidence on channels in controlled firms”, Corporate Governance: An International Review, Vol. 23 No. 2, pp. 83-103.

Ashforth, B.E. and Mael, F. (1989), “Social identity theory and the organization”, Academy of Management Review, Vol. 14, pp. 20-39.

Bantel, K.A. (1993), “Strategic clarity in banking: role of top management-team demography”, Psychological Reports, Vol. 73, pp. 1187-1201.

Bantel, K.A. and Jackson, S. (1989), “Top management and innovations in banking: Does the demography of the top team make a difference?”, Strategic Management Journal, Vol. 10, pp. 107-124.

Bøhren, Ø. and Staubo, S. (2014), "Does mandatory gender balance work? Changing organizational form to avoid board upheaval”, Journal of Corporate Finance, Vol. 28, pp. 152-168. 
Bunderson, J.S. and Sutcliffe, K. (2002), “Comparing Alternative Conceptualizations of Functional Diversity in Management Teams: Process and Performance Effects”, Academy of Management Journal, Vol. 45 No. 5, pp. 875-893.

Campbell, K. and Mínguez-Vera, A. (2008), “Gender Diversity in the Boardroom and Firm Financial Performance”, Journal of Business Ethics, Vol. 83 No. 3, pp. 435-451.

Carpenter, M.A., Geletkanycz, M.A. and Sanders, W.G. (2004), “Upper echelons research revisited: antecedents, elements, and consequences of top management team composition”, Journal of Management, Vol. 30 No. 6, pp. 749-778.

Carter, D., D’Souza, F., Simkins, B. and Simpson, W. (2010), “The gender and ethnic diversity of US boards and board committees and firm financial performance”, Corporate Governance: An International Review, Vol. 18 No. 5, pp. 396-414.

Carter, D., Simkins, B. and Simpson, G. (2003), “Corporate Governance, Board Diversity, and firm value”, The Financial Review, Vol. 38 No. 1, pp. 33-53.

Carter, N. and Williams, M. (2003), “Comparing social feminism and liberal feminism: The case of new firm growth”, in Butler, J. (2003), New perspectives on women entrepreneurs. Information age publishing. USA. Cap. 2, pp. 25-50.

CWDI (2015), “2015 CWDI Report: Women Board Directors of 100 Largest Latin American Companies”, Corporate Women Directors International. Washington: USA.

Delloite (2015), “Diversidad en los Consejos de Administración, Boletín de Gobierno Corporativo”, Invierno 2014/Enero de 2015: Mexico.

Delloite, (2017), “Mujeres en los Consejos de Administración: Una perspectiva global”, Delloite Mexico: Mexico.

Dezsö, C.L. and Ross, D.G. (2012), “Does female representation in top management improve firm performance? A panel data investigation”, Strategic Management Journal, Vol. 33 No. 9, pp. 1072-1089. 
Dwyer, S., Richard, O.C. and Chadwickc, K. (2003), “Gender diversity in management and firm performance: the influence of growth orientation and organizational culture”, Journal of Business Research, Vol. 56 No. 12, pp. 1009-1019.

Engel, E., Hayes, R.M. and Wang, X. (2003), “CEO turnover and properties of accounting information”, Journal of Accounting and Economics, Vol. 36 No. 1, pp. 197-226.

Erhardt, N.L., Werbel, J.D. and Shrader, C.B. (2003), “Board of director diversity and firm financial performance”, Corporate Governance: An International Review, Vol. 11 No. 2, pp. 102-111.

Fisman, R.J., Khurana, R., Rhodes-Kropf, M. and Yim, S. (2014), “Governance and CEO turnover: Do something or do the right thing?”, Management Science, Vol. 60 No. 2, pp. 319-337.

Greene, W. (2003), Econometric Analysis, Prentice Hall, Upper Saddle River, NJ.

Hambrick, D. (2007), “Upper Echelons Theory: An Update”, Academy of Management Review, Vol. 32 No. 2, pp. 334-343.

Hambrick, D., Cho, T. and Chen, M. (1996), “The influence of top management team heterogeneity on firms’ competitive moves”, Administrative Science Quarterly, Vol. 41, pp. 659-84.

Hambrick, D. and Mason, P. (1984), “Upper Echelons: The Organization as a Reflection of Its Top Managers”, Academy of Management Review, Vol. 9 (2), 193 - 206.

Hausman, J. (1978), “Specification Tests in Econometrics”, Econometrica, Vol. 46 No. 6, pp. 12511271.

Herman, J. and Smith, B. (2015). Upper Echelons Theory. Wiley Encyclopedia of Management. 6 (1), John Wiley \& Sons: West Sussex, UK.

Hermalin, B. and Weisbach, M. (2003), “Board of directors as an endogenously determined institution: a survey of the economic literature”, FRBNY Economic Policy Review, Vol. 9, pp. 726.

Hillman, A.J. and Dalziel, T. (2003), “Boards of directors and firm performance: Integrating agency and resource dependence perspectives”, Academy of Management Review, Vol. 28, pp. 383-396. 
Hillman, A.J., Shropshier, C. and Cannella, A.A. (2007), “Organizational predictors of women on corporate boards”, Academy of Management Journal, Vol. 50 No. 4, pp. 941-952.

Hillman, A.J. (2015), “Board diversity: Beginning to unpeel the onion”, Corporate governance: An International Review, Vol. 23 No. 2, pp. 104-107.

Hoogendoorn, S., Oosterbeek, H. and Van Praag, M. (2013), “The impact of gender diversity on the performance of business teams: Evidence from a field experiment”, Management Science, Vol. 59 No. 7, pp. 1514-1528.

International Labour Organization (ILO) (2015), “Women in business and management: Gaining momentum”, International Labour Office, Geneva (Switzerland). ISBN 978-92-2-128873-2.

Isidro, H. and Sobral, M. (2015), “The Effects of Women on Corporate Boards on Firm Value, Financial Performance, and Ethical and Social Compliance”, Journal of Business Ethics, Vol. 132 No. 1, pp. 1-19.

Jeong, S.H. and Harrison, D. (2017), “Glass Breaking, Strategy Making, and Value Creating: MetaAnalytic Outcomes of Females as CEOs and TMT members”, Academy of Management Journal, in press (doi: 10.5465/amj.2014.0716).

Joecks, J., Pull, K. and Vetter, K. (2013), “Gender diversity in the boardroom and firm performance: What exactly constitutes a ‘critical mass'?”, Journal of Business Ethics, Vol. 118 No. 1, pp. 61-72.

Kiliç, M. and Kuzey, C. (2016), “The effect of board gender diversity on firm performance: evidence from Turkey”, Gender in Management: An International Journal, Vol. 31 No. 7, pp. 434-455.

Klein, K. (2017), “Does Gender Diversity on Boards Really Boost Company Performance?”, Social Impact, Wharton - University of Pennsylvania. Available online: http://knowledge.wharton.upenn.edu/article/will-gender-diversity-boards-really-boost-companyperformance/ 
Klettner, A., Clarke, T. and Boersma, M. (2016), “Strategic and regulatory approaches to increasing women in leadership: multilevel targets and mandatory quotas as levers for cultural change”, Journal of Business Ethics, Vol. 133 No. 3, pp. 395-419.

Krishnan, H.A. and Park, D. (2005), “A few good women: On top management teams”, Journal of Business Research, Vol. 58 No. 12, pp. 1712-1720.

Lazzaretti, K., Kleinübing Godoi, C., Parodi Oliveira Camilo, S. and Marcon, R. (2013), “Gender diversity in the boards of directors of Brazilian businesses”, Gender in Management: An International Journal, Vol. 28 No. 2, 94-110.

Liu, Y., Wei, Z. and Xie, F. (2014), "Do women directors improve firm performance in China?”, Journal of Corporate Finance, Vol. 28, pp. 169-184.

Lückerath-Rovers, M. (2013), “Women on boards and firm performance”, Journal of Management \& Governance, Vol. 17 No. 2, pp. 491-509.

Mahadeo, J.D., Soobaroyen, T. and Hanuman, V.O. (2012), “Board composition and financial performance: Uncovering the effects of diversity in an emerging economy”, Journal of Business Ethics, Vol. 105 No. 3, 375-388.

Martin, L.M., Warren-Smith, I., Scott, J.M. and Roper, S. (2008), Boards of directors and gender diversity in UK companies”, Gender in Management: An International Journal, Vol. 23 No. 3, pp. 194-208.

Naranjo-Gil, D., Hartmann, F. and Maas, V.S. (2008), “Top management team heterogeneity, strategic change and operational performance”, British Journal of Management, Vol. 19 No. 3, pp. 222-234.

Nishii, L., Gotte, A. and Raver, J. (2007), “Upper echelon theory revisited: The relationship between upper echelon diversity, the adoption of diversity practices, and organizational performance”, CAHRS Working Paper \#07- 04. Ithaca, NY: Cornell University, School of Industrial and Labor Relations, Center for Advanced Human Resource Studies. 
Oppong, S. (2014), “Upper echelons theory revisited: The need for a change from causal description to casual explanation”, Management: Journal of Contemporary Management Issues, Vol. 19 No. 2, pp. 169-183.

Palvia, A., Vähämaa, E. and Vähämaa, S. (2014), “Are Female CEOs and Chairwomen More Conservative and Risk Averse? Evidence from the Banking Industry during the Financial Crisis”, Journal of Business Ethics, Vol. 131 No. 3, pp. 1-18.

Pfeffer, J. and Salancik, G.R. (1978). The external control of organizations: A resource dependence perspective, New York, Harper Row.

Post, C. and Byron, K. (2015), “Women on Boards and Firm Financial Performance: A MetaAnalysis”, Academy of Management Journal, Vol. 58 No. 5, pp. 1546-1571.

Ravasi, D. and Schultz, M. (2006), "Responding to organizational identity threats: Exploring the role of organizational culture”, Academy of Management Journal, Vol. 49 No. 3, pp. 433-458.

Reguera-Alvarado, N., de Fuentes, P. and Laffarga, J. (2015), “Does board gender diversity influence financial performance? Evidence from Spain”, Journal of Business Ethics, Vol. 141 No. 2, pp. 337-350.

Robbins, S. (1974), Managing Organizational Conflict: A Nontraditional Approach, Englewood Cliffs (New Jersey), Prentice. Hall.

Rose, C. (2007), “Does female board representation influence firm performance? The Danish evidence”, Corporate Governance: An International Review, Vol. 15 No. 2, pp. 402-413.

Rosener, J.B. (1995), America’s competitive secret: Utilizing women as a management strategy, New York, Oxford University Press.

Sekkat, K., Szafarz, A., Tojerow, I. (2015), Women at the Top in Developing Countries: Evidence from Firm-Level Data, IZA Discussion Paper No. 9537.

Singh, V., Point, S. and Moulin, Y. (2015), “French supervisory board gender composition and quota threat: changes from 2008 to 2010”, Gender in Management: An International Journal, Vol. 30 No. 7, pp. 551-571. 
Tajfel, H. (1981), Human groups and social categories, Cambridge, Cambridge University Press.

Tang, J., Crossan, M. and Rowe, W.G. (2011), “Dominant CEO, deviant strategy, and extreme performance: The moderating role of a powerful board”, Journal of Management Studies, Vol. 48 No. 7, pp. 1479-1503.

Terjesen, S., Couto, E.B. and Francisco, P.M. (2016), “Does the presence of independent and female directors impact firm performance? A multi-country study of board diversity”, Journal of Management \& Governance, Vol. 20 No. 3, pp. 447-483.

Ting, I.W.K., Azizan, N.A.B., Kweh, Q.L. (2015), “Upper echelon theory revisited: The relationship between CEO personal characteristics and financial leverage decision”, ProcediaSocial and Behavioral Sciences, Vol. 195, pp. 686-694.

Van Knippenberg, D., De Dreu, C.K.W. and Homan, A.C. (2004), “Work group diversity and group performance: An integrative model and research agenda”, Journal of Applied Psychology, Vol. 89 No. 6, pp. 1008-1022.

Waldman, D., Javidan, M. and Varella, P. (2004), “Charismatic leadership at the strategic level: A new application of upper echelons theory”, The Leadership Quarterly, Vol. 15, pp. 355-380.

Williams, R., Hoffman, J. and Lamont, B. (1995), “The influence of top management team characteristics on M-form implementation time”, Journal of Managerial Issues, Vol. 7, pp. 466480.

Wooldridge, J. (2002), Econometric Analysis of Cross Section and Panel Data, The MIT Press, Cambridge, MA.

World Economic Forum (2015), The Global Gender Gap Report 2016, World Economic Forum, Geneva, Switzerland. Available at: http://reports.weforum.org/global-gender-gap-report2016/the-global-gender-gap-report-2016/. 


\section{List of Figures}

Figure 1. Women representation (Board and top management team) in Colombian listed businesses

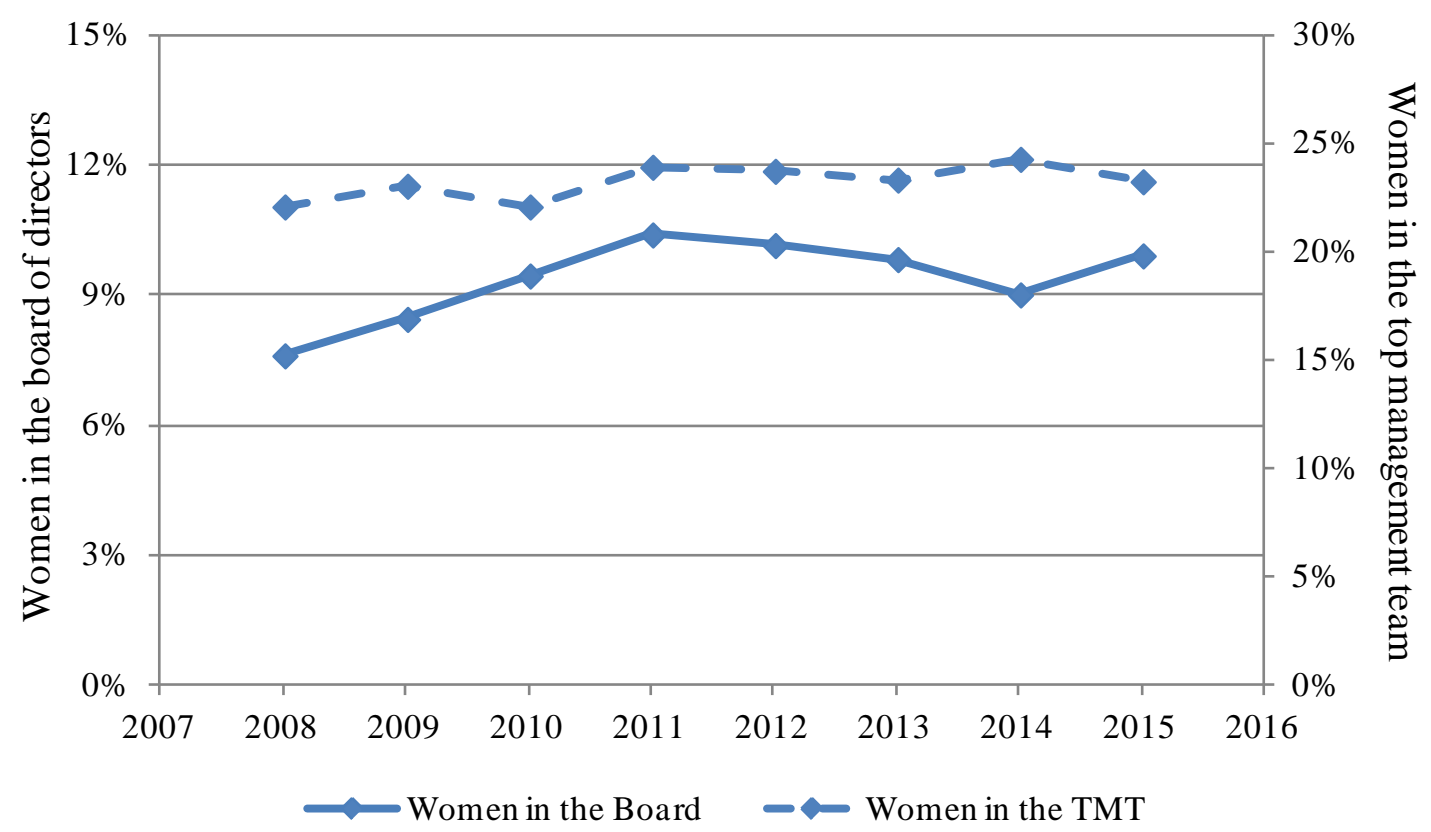

Source: Authors' elaboration based on the study data. 


\section{List of Tables}

Table 1. Descriptive statistics and bivariate correlation matrix (period 2008-2015)

\begin{tabular}{|c|c|c|c|c|c|c|c|c|c|c|c|c|}
\hline & & Mean & $\begin{array}{r}\text { Standard } \\
\text { deviation }\end{array}$ & 1 & 2 & 3 & 4 & 5 & 6 & 7 & 8 & 9 \\
\hline 1 & $\begin{array}{l}\text { Return on } \\
\text { assets (ROA) }\end{array}$ & 0.0496 & 0.0678 & 1.000 & & & & & & & & \\
\hline 2 & $\begin{array}{l}\text { Return on } \\
\text { equity (ROE) }\end{array}$ & 0.1297 & 0.6316 & $0.507 * * *$ & 1.000 & & & & & & & \\
\hline 3 & $\begin{array}{l}\text { Women on the } \\
\text { board (\%) }\end{array}$ & 0.0935 & 0.1236 & $0.113 * *$ & 0.042 & 1.000 & & & & & & \\
\hline 4 & $\begin{array}{l}\text { Women in top } \\
\text { management } \\
\text { team (\%) }\end{array}$ & 0.2321 & 0.2080 & -0.001 & 0.072 & $0.143^{* * *}$ & 1.000 & & & & & \\
\hline 5 & $\begin{array}{l}\text { Woman as } \\
\text { CEO }\end{array}$ & 0.1227 & 0.3285 & $0.181^{* * *}$ & 0.015 & $0.310 * * *$ & $0.280 * * *$ & 1.000 & & & & \\
\hline 6 & $\begin{array}{l}\text { Top } \\
\text { management } \\
\text { team size }\end{array}$ & 9.2778 & 4.3133 & $0.120^{* *}$ & 0.027 & 0.015 & $0.168 * * *$ & $-0.114^{* *}$ & 1.000 & & & \\
\hline 7 & $\begin{array}{l}\text { Size of board } \\
\text { of directors }\end{array}$ & 6.4352 & 1.4957 & $0.144 * * *$ & -0.033 & 0.026 & -0.028 & $-0.161^{* * *}$ & $0.305^{* * *}$ & 1.000 & & \\
\hline 8 & $\begin{array}{l}\text { Board } \\
\text { independence } \\
\text { rate }\end{array}$ & 0.4878 & 0.2261 & -0.029 & -0.003 & $0.122 * *$ & $-0.109 * *$ & 0.014 & -0.018 & -0.035 & 1.000 & \\
\hline 9 & $\begin{array}{l}\text { Total assets } \\
\text { (million of } \\
\text { constant US\$) }\end{array}$ & $4,512.89$ & 8,732.68 & -0.006 & 0.002 & $-0.087^{*}$ & $-0.087 *$ & $-0.152 * * *$ & $0.319 * * *$ & $0.156^{* * *}$ & $0.190 * * *$ & 1.000 \\
\hline 10 & $\begin{array}{l}\text { Leverage } \\
\text { (debt to assets) }\end{array}$ & 0.4114 & 0.2742 & $-0.194^{* * *}$ & $0.083^{*}$ & $-0.129 * * *$ & $0.154^{* * *}$ & -0.062 & $0.262^{* * *}$ & $-0.125 * * *$ & $0.128 * * *$ & $0.310 * * *$ \\
\hline
\end{tabular}

Total number of observations: 432 (54 businesses). *, **, *** indicate significanc at the 10\%, 5\% and 1\%, respectively. 
Table 2. Fixed-effects regression results: The role of gender diversity on business performance

\begin{tabular}{|c|c|c|c|c|c|c|c|c|}
\hline & \multicolumn{4}{|c|}{ Dependent variable: Return on assets (ROA) } & \multicolumn{4}{|c|}{ Dependent variable: Return on equity (ROE) } \\
\hline & Model 1 & Model 2 & Model 3 & Model 4 & Model 1 & Model 2 & Model 3 & Model 4 \\
\hline $\begin{array}{l}\text { Women on the board (\%) } \\
t-1\end{array}$ & $\begin{array}{c}0.0382 \\
(0.0402)\end{array}$ & & & $\begin{array}{c}0.0385 \\
(0.0387)\end{array}$ & $\begin{array}{l}1.5433^{* * *} \\
(0.5459)\end{array}$ & & & $\begin{array}{c}1.5457 * * * \\
(0.5169)\end{array}$ \\
\hline $\begin{array}{l}\text { Women in top } \\
\text { management team (\%) } t-1\end{array}$ & & $\begin{array}{c}0.1871^{* * *} \\
(0.0386) \\
\end{array}$ & & $\begin{array}{c}0.1856 * * * \\
(0.0384)\end{array}$ & & $\begin{array}{c}3.1550^{* * * *} \\
(0.5187)\end{array}$ & & $\begin{array}{c}3.1541^{* * *} \\
(0.5131)\end{array}$ \\
\hline Woman as CEO $t-1$ & & & $\begin{array}{l}0.0985 * * \\
(0.0535)\end{array}$ & $\begin{array}{l}0.0931^{*} \\
(0.0517)\end{array}$ & & & $\begin{array}{c}0.2150 \\
(0.7380)\end{array}$ & $\begin{array}{c}0.1240 \\
(0.6904)\end{array}$ \\
\hline $\begin{array}{l}\text { Top management team } \\
\text { size }(\ln ) t-1\end{array}$ & $\begin{array}{c}0.0104 \\
(0.0184)\end{array}$ & $\begin{array}{c}0.0131 \\
(0.0177)\end{array}$ & $\begin{array}{c}0.0101 \\
(0.0183)\end{array}$ & $\begin{array}{c}0.0135 \\
(0.0177)\end{array}$ & $\begin{array}{l}0.6005^{* *} \\
(0.2491)\end{array}$ & $\begin{array}{c}0.6391 * * * \\
(0.2386)\end{array}$ & $\begin{array}{l}0.5864 * * \\
(0.2522)\end{array}$ & $\begin{array}{c}0.6534^{* * *} \\
(0.2361)\end{array}$ \\
\hline Board size $(\ln ) t-1$ & $\begin{array}{c}0.0406 \\
(0.1015)\end{array}$ & $\begin{array}{c}0.0426 \\
(0.0979)\end{array}$ & $\begin{array}{c}0.0321 \\
(0.1010) \\
\end{array}$ & $\begin{array}{c}0.0433 \\
(0.0977)\end{array}$ & $\begin{array}{c}0.3877 \\
(1.3769)\end{array}$ & $\begin{array}{c}0.3151 \\
(1.3171)\end{array}$ & $\begin{array}{c}0.1978 \\
(1.3930)\end{array}$ & $\begin{array}{c}0.4915 \\
(1.3044)\end{array}$ \\
\hline Board independence $t-1$ & $\begin{array}{c}0.0399 \\
(0.1140)\end{array}$ & $\begin{array}{c}0.0289 \\
(0.1101)\end{array}$ & $\begin{array}{c}0.0379 \\
(0.1136)\end{array}$ & $\begin{array}{c}0.0325 \\
(0.1097)\end{array}$ & $\begin{array}{l}0.3055^{* *} \\
(0.1547)\end{array}$ & $\begin{array}{l}0.2562^{*} \\
(0.1481)\end{array}$ & $\begin{array}{l}0.2958^{*} \\
(0.1566)\end{array}$ & $\begin{array}{l}0.2687^{*} \\
(0.1466)\end{array}$ \\
\hline Firm size (ln assets) $t-1$ & $\begin{array}{c}-0.0037^{* *} \\
(0.0018) \\
\end{array}$ & $\begin{array}{l}-0.0031^{*} \\
(0.0017) \\
\end{array}$ & $\begin{array}{c}-0.0032^{*} \\
(0.0018) \\
\end{array}$ & $\begin{array}{c}-0.0029^{*} \\
(0.0017) \\
\end{array}$ & $\begin{array}{l}-0.0145 \\
(0.0380) \\
\end{array}$ & $\begin{array}{l}-0.0044 \\
(0.0364) \\
\end{array}$ & $\begin{array}{l}-0.0126 \\
(0.0386)\end{array}$ & $\begin{array}{l}-0.0046 \\
(0.0362) \\
\end{array}$ \\
\hline $\begin{array}{l}\text { Leverage (debt to assets } \\
\text { ratio) } t-1\end{array}$ & $\begin{array}{c}-0.0892^{*} \\
(0.0518)\end{array}$ & $\begin{array}{c}-0.0880^{*} \\
(0.0511)\end{array}$ & $\begin{array}{l}-0.0845^{*} \\
(0.0480)\end{array}$ & $\begin{array}{l}-0.0801^{*} \\
(0.0411)\end{array}$ & $\begin{array}{c}-1.7463 * * \\
(0.7055)\end{array}$ & $\begin{array}{c}-1.7264 * * \\
(0.6874)\end{array}$ & $\begin{array}{c}-1.9373 * * * \\
(0.7168)\end{array}$ & $\begin{array}{c}-1.7084^{* *} \\
(0.6822)\end{array}$ \\
\hline Time dummies & Yes & Yes & Yes & Yes & Yes & Yes & Yes & Yes \\
\hline Intercept & $\begin{array}{c}0.0710 \\
(0.2079) \\
\end{array}$ & $\begin{array}{c}0.0239 \\
(0.2007) \\
\end{array}$ & $\begin{array}{c}0.0615 \\
(0.2070) \\
\end{array}$ & $\begin{array}{l}-0.0117 \\
(0.2008) \\
\end{array}$ & $\begin{array}{l}-1.1342 \\
(2.8215) \\
\end{array}$ & $\begin{array}{l}-1.6025 \\
(2.7003) \\
\end{array}$ & $\begin{array}{l}-0.6250 \\
(2.8553) \\
\end{array}$ & $\begin{array}{l}-2.1929 \\
(2.6821) \\
\end{array}$ \\
\hline F-test & $1.78^{*}$ & $2.89 * * *$ & $2.12 * * *$ & $2.81 * * *$ & $1.88 * *$ & $4.41 * * *$ & $1.69 * *$ & $4.50 * * *$ \\
\hline R2 (within) & 0.0349 & 0.1001 & 0.0425 & 0.1121 & 0.0674 & 0.1449 & 0.0438 & 0.1689 \\
\hline VIF $(\min -\max )$ & $\begin{array}{c}1.43 \\
(1.03-1.73) \\
\end{array}$ & $\begin{array}{c}1.43 \\
(1.04-1.73) \\
\end{array}$ & $\begin{array}{c}1.43 \\
(1.02-1.73) \\
\end{array}$ & $\begin{array}{c}1.42 \\
(1.06-1.73) \\
\end{array}$ & $\begin{array}{c}1.43 \\
(1.03-1.73) \\
\end{array}$ & $\begin{array}{c}1.43 \\
(1.04-1.73)\end{array}$ & $\begin{array}{c}1.43 \\
(1.02-1.73) \\
\end{array}$ & $\begin{array}{c}1.42 \\
(1.06-1.73) \\
\end{array}$ \\
\hline Observations & 378 & 378 & 378 & 378 & 378 & 378 & 378 & 378 \\
\hline
\end{tabular}

Robust standard errors are presented in brackets. *, **, *** indicate significance at the $10 \%, 5 \%$ and $1 \%$, respectively. 
